\title{
DUAL OREXIN RECEPTOR ANTAGONIST IN TREATMENT OF INSOMNIA
}

\author{
Nikola Trajanović
}

UDK: 619.959 .7

doi: 10.5937/engrami41-29093

\section{Summary}

A novel group of medications, dual orexin receptor antagonists, emerged as a competent group that challenges current first-line hypnotics. They have relatively infrequent and mostly well-tolerated side effects, primarily in the form of residual somnolence, fatigue and nightmares/disturbing dreams. The advantage over conventional hypnotics stems from the specifics of their target receptors, which translates into lack of tolerance after long term use and good safety profile. They are particularly favoured in some specific populations, including the elderly. Ongoing and future studies are set to explore their effect on selected conditions, such as addiction and psychiatric disorders, dementias, perimenopausal condition and circadian rhythm disorders, to name a few.

Key words:

orexin, antagonists, therapy, insomnia 


\section{REVIEW}

The quest for novel treatments for insomnia is never abating, and new compounds are regularly introduced into the clinical practice. In recent years, a new group of medication has been discovered, targeting orexin receptors and bringing a new approach to the management of insomnia.

Insomnia is one of the most prevalent medical conditions affecting a large proportion of population ( $10 \%$ of adults report persistent complaint of insomnia), and consists of difficulty falling asleep, difficulty staying asleep, waking up too early, or feeling unrefreshed after sleep ${ }^{[1]}$. If persisting for a prolonged period, it may cause problems in daily functioning, feeling of tiredness or sleepiness, changes in mood, increased irritability and decreased work performance. It is also linked to a number of medical disorders, often in a bidirectional causation (cardiovascular disorders, mental disorders, endocrine/metabolic disorders, etc. $)^{[2]}$.

Treatment of insomnia ${ }^{[3,4]}$ involves both pharmaceutical and non-pharmaceutical interventions, as well as adherence to the set of behavioural or lifestyle measures so called "sleep hygiene". The most common drugs used in the treatment of insomnia are benzodiazepines (BZD), although only a few of these have been officially approved for such an indication. They act primarily on $\gamma$-ami- nobutyric-a (GABAa) receptors that are widely distributed throughout the central nervous system (CNS). As a result, apart from the somniferous effect, they also exercise other effects in the form of sedation, muscle relaxation and anxiolysis. They may also have an anti-convulsive effect. On the other hand, as a result of their generalized effect on CNS, they can cause unwanted phenomena, such as anterograde amnesia, dissociation and loss of motor coordination, to name a few. Another shortcoming of BZDs is the occurrence of tolerance and dependence after prolonged use, as well as a benzodiazepine withdrawal syndrome, a cluster of serious psychological and physical symptoms and signs that might potentially be life-threatening. For the reason of safety, benzodiazepines are limited to up to 4 weeks of continuous use. Prolonged use of BZDs has also been linked to dementia and cancer ${ }^{[5]}$.

The second large group are non-benzodiazepine hypnotics, or "Z-hypnotics" (zolpidem, zaleplone, zopiclone, eszopiclone). They also act upon the GABAa receptors, however, being sub-unit selective, they cause less secondary effects and have a better safety profile, and are consequently more often prescribed in the elderly population. Extended release zolpidem and eszopiclone do not have Food and Drug Administration (FDA) limitation on how long then could be used to treat insomnia. As a special caveat, Z-hypnotics (primarily zolpidem) 
can cause complex sleep behaviours, and are also linked to dementia and cancer $^{[5]}$.

Other medications are less frequently used as hypnotics, mostly due to their secondary effects targeting non-GABA receptors. These include older $\mathrm{H} 1$ antihistamines, antidepressants (trazodone, some tricyclic and tetracyclic antidepressants), antipsychotics (primarily 2nd generation), and alpha-adrenergic agonists. Most of the medications that were used in the past as hypnotics are no longer in use or they are in a very limited use, such is the case with chloral-hydrate, barbiturates and quinazolinones (methaqualone).

In recent years, there has been an increased pressure to find selective site-specific hypnotic with a better safety profile. However, this also resulted in these medications having some limitations, both in the terms of the type of insomnia they can effectively treat, and in the magnitude of their soporific effect. An illustrative example for this is melatonin and melatonin MT1/MT2 receptor agonists. When introduced, they were met with great expectations that this novel approach will bring an end to (or at least a significant reduction) in use of BZDs and Z-hypnotics. Without the good understanding of their mechanism of action, they were indiscriminately prescribed for all types of insomnia, and with little regard to their chronobiological properties. The initial promise was largely unfulfilled and their impact on insomnia treatment is today rather limited (the now well-known melatonin is here faring better, since it can be obtained over the counter). When used properly, MT agonists can be reasonably effective. These medications are best used to treat sleep onset insomnia, and melatonin itself should be used in advance of the expected sleep cycle and not immediately before going to bed. They do not have a proper sedative-hypnotic effect; instead, they heighten sleep promoting property of the target receptors in the suprachiasmatic nucleus. Aside from the sleep onset insomnia, melatonin and MT agonists can be used to treat circadian rhythm disorders. They currently do not have a limitation on how long they can be used.

Another group of initially promising compounds are neurokinin 1 (NK1) antagonists. They impact, among other sites, the arousal centres in the CNS by blocking the activating effect of the substance $\mathrm{P}$ and neurokinines through binding to NK1 receptors, thus inducing sleep. A single study of vestipitant has shown a favourable effect on sleep maintenance, but further research has not been forthcoming ${ }^{[6]}$.

Orexin is primarily an excitatory neuropeptide which regulates the sleepwake cycle by promoting wakefulness and arousal. It is also involved in the regulation of energy expenditure and appetite. It was discovered in 1998 in- 
dependently by two research teams - a Japanese-American team who named it $\operatorname{orexin}^{[7]}$, stemming from "appetite" in Greek, and an American-Norwegian team who named it hypocretin ${ }^{[8]}$, for its location in hypothalamus and resemblance to hormone secretin. Both of these names are in concurrent use, hypocretin for the gene and its transcripts, and orexin for the peptide itself. Appetite was the first function regulated by orexin that was identified. Later studies discovered its role in sleep-wake regulation, which led to the understanding of the comprehensive system that integrates sleep, metabolism, need for food and circadian rhythmicity.

Orexin neurons activate various neural circuitries, involving acetylholine, dopamine, norepinephrine and histamine ${ }^{[9]}$. Secretion from the lateral hypothalamus promotes arousal and wakefulness, while the blockade causes sleepiness. So far, two types of receptors were identified -orexin 1 (Ox1R), binding primarily peptide orexin $\mathrm{A}(\mathrm{OxA})$, and orexin 2 receptor $(\mathrm{Ox} 2 \mathrm{R})$, binding equally both $\mathrm{OxA}$ and orexin $\mathrm{B}(\mathrm{OxB})$. OxA is more stable and more lipophilic of the two peptides. Both Ox1R and $\mathrm{Ox} 2 \mathrm{R}$ are $\mathrm{G}$ protein-coupled types of receptors. It was also discovered that genetic mutations of orexin receptors in animal models are associated with canine narcolepsy, which prompted further research that showed decreased orexin levels in patients suffering from this sleep disorder. Cardinal symptoms of narcolepsy include excessive daytime sleepiness, often in the form of uncontrollable sleep attacks, disturbed nocturnal sleep and cataplexy, usually triggered by an emotional arousal. On the other hand, central administration of orexin induces wakefulness. In terms of diurnal fluctuations, orexin neurons are exhibiting a high level of activity during wakefulness and low level during sleep. They show sensitivity to input primarily from glutamate and adenosine pathways, and also to corticotropin releasing hormone, muscarine, neuropeptide Y, cholecystokinin and monoamine neurons, respective to their activating or inhibitory function, as well as to ghrelin, leptin and glucose. GABA projections to lateral hypothalamus are also abundant, but, notably, they do not create functional synapses. Orexin neurons project broadly to numerous higher and lower regions of the brain. To add further complexity to the understanding of the orexin system, it was discovered that a small percentage $(<20 \%)$ of orexin neurons also have a potential for GABA synthesis, and co-express other neuropeptides, such as dynorphin.

Sleep is primarily regulated by an intricate relationship of different neuronal populations (serotonergic, GABAergic, dopaminergic, cholinergic, norepinephrinergic). They show diurnal variability which defines cardinal sleep-wake stages - wakefulness, NREM sleep and REM 
sleep. This is also true for orexin neurons. They are mostly active during the active wakefulness, but their rate of firing dramatically decreases during quiet wakefulness, and is almost non-existent during NREM sleep. During REM sleep their activity is not existent, to be slightly increased towards the end of REM cycles. Orexin levels also show seasonal variations, correlating to the duration of the daylight. In theory, effective suppression of orexin neurons would be expected to reverse heightened arousal and active wakefulness, and transform it into uninterrupted sleep. Secondary outcome might be a mild reduction in REM sleep or dream recall, considering physiological levels of orexin during REM cycles. It has been established that induced activation of Ox1R suppresses predominantly REM sleep, while activation of Ox2R suppresses both REM and NREM sleep.

It took some time from the discovery of the orexin system to the development of an effective medication that utilizes its properties ${ }^{[10,11]}$. Suvorexant, the first dual orexin receptor antagonist (DORA) was introduced in 2014 ${ }^{[12]}$. The second and last medication to be approved so far has been lemborexant, introduced in December 2019 ${ }^{[13]}$. The indications for both are initial and maintenance insomnia, without term limitation for their use. Both of these orexin receptor antagonists bind reversibly to Ox1R and Ox2R. Their time to peak levels is $2+/$ -
$1 \mathrm{~h}$ and elimination half-life 12 hours for suvorexant and 17-19 hours for lemborexant. They are metabolised by hepatic CYP3A enzyme and excreted by feces and, to a lesser degree, by urine. Pharmacokinetcs are not affected by age, but higher concentration could be expected in obese patients and females.

Compared to placebo, DORA show mild reduction of the sleep latency duration (9 minutes) and wakefulness after sleep onset (up to 25 minutes) ${ }^{[14,15]}$. The effect was maintained after a month of nightly use. Suvorexant $20 \mathrm{mg}$ showed continued effect after three months, with sleep latency decreased by 6 minutes, and wake after sleep onset by 16 minutes, compared to placebo. Higher dose (40 mg) showed further improvement, but more side-effects (somnolence, nightmares, fatigue, headache, xerostomia and peripheral oedema). Lemborexant showed similar efficacy compared to placebo, and also comparable side-effects (the most frequent was somnolence, dose dependant, $10 \%$ of patients at $10 \mathrm{mg}$ dose). It also showed somewhat better results in both sleep onset latency and total sleep time when compared to zolpidem, particularly at $10 \mathrm{mg}$ dose (SOL -7 min initially, and -14 min at 30 days; TST $+4 \%$ initially and $+5 \%$ at 30 days), and a more significant difference when compared to placebo (SOL $-13 \mathrm{~min}$ and TST $+7.5 \%$ at 30 days $)^{[13]}$. Interestingly, these studies ${ }^{[10-15 \text {, }}$ ${ }^{16]}$ also reported some form of insomnia 
as a side effect after short or long term use. However, considering the reason for DORA use, this is rather an indication that in considerable number of patients these medications have little to no effect. There were rare occurrences of hallucinations, sleep paralysis and parasomnia, particularly at higher doses, with isolated reports of cataplexy. For this reason, DORAs should not be used in patients with narcolepsy. The question why DORA orexin blockade does not universally cause narcolepsy is best explained by the fact that, for narcolepsy to be clinically manifested, a total, or almost total blockade must occur. Obviously, in case of DORA use, it is highly unlikely that total blockade would happen.

A direct comparisons to other hypnotics has not been done in a research setting so far. However, an analysis of adverse events reported to the FDA regulatory database ${ }^{[16]}$ offered some insight into a difference between suvorexant, zolpidem, ramelteon (MT agonist), zaleplon and eszopiclone. Suvorexant had a highest report of ineffectiveness or incomplete drug effect (odds ratio 95\% CI of 2.52), followed by zaleplon and ramelteon. Eszopiclone and zolpidem were clustered together with the fewest reports of ineffectiveness. While suvorexant has a higher incidence for nightmares/disturbing or abnormal dreams, it has much lower incidence for the range of parasomnic behaviours, unlike zolpidem.
DORA have higher addiction potential then previously expected - they are comparable to Z-hypnotics, and for this reason they are classified in the same group of controlled substances. However, rare studies in the relatively short post-marketing period showed that they have a lower incidence of abuse-related events (euphoria, hallucinations) when compared to zolpidem. The addiction potential has been constant at all dosage levels, unlike zolpidem where the potential increases with the dose. The tolerance levels are superior to Z-hypnotics and BZDs, so they present a viable option for a long-term use in chronic insomnia, and they are not associated with rebound insomnia ${ }^{[17,18,19]}$.

Over the relatively short period since the introduction, DORAs have been tested in specific populations and disorders. Due to the mechanism of action that does not involve non-selective central inhibition, these drugs can be given to patients suffering from obstructive sleep apnoea. Study of lemborexant in elderly population ${ }^{[13]}$ showed impairment of balance after forced awakening 4 hours into sleep, and also dose-dependant impairment of memory and attention. However, test of next-day stability, memory and attention showed no difference compared to placebo, and the driving ability tested 9 hours after taking medication showed little to no difference when compared to placebo (notably, 10 $\mathrm{mg}$ dose caused small decrease in driv- 
ing ability). Suvorexant showed comparable results in the driving ability test ${ }^{[20]}$. There have been no studies on the high risk and difficult to treat groups, such as children and pregnant women, but the guidelines for treatment ${ }^{[21]}$ might be amended in the near future. Currently, suvorexant is in category $\mathrm{C}$ of the FDA, showing minimal risk (decreased fetal body weight), based on the animal studies, and lemborexant is not yet categorized. All other major hypnotics are also in the category $\mathrm{C}$.

Suvorexant has been shown to significantly improve sleep in shift-workers and other circadian rhythm disturbanc$\mathrm{es}^{[19]}$. The sleep benefit for shift workers could add up to 2 hours of sleep per sleep cycle. The study reports mild side effect and that the drug was well tolerated in this sample. Another meta-analysis suggests favourable effect of suvorexant on delirium prevention in peri-operative and acute care patients ${ }^{[20]}$. However, the findings were contrasted with some reports that suvorexant has the opposite effect, which warrants further research in this area. A particular target for DORAs use are patients with Alzheimer's dementia, and other types of dementia. Double blind studies of use of suvorexant in patients with this disorder showed improved sleep and side effects that were comparable to those seen in general population who use this medication $^{[24]}$. DORAs could be further useful in treating accompanying symptoms, such as delirium and circadian rhythm disruptions.

An interesting area that is emerging is that of addiction, with reports suggesting that DORAs may help in treatment of opioid and cocaine addiction, and alcohol abuse ${ }^{[25,26]}$. The premise for these is that orexin Ox1R signalling triggers psychostimulant-seeking behaviour, and that selective orexin blockade may inhibit the exaggerated craving, while the rest of physiological drives remaining unaffected.

\section{Conclusion}

Dual orexin receptor antagonists introduce a new perspective on insomnia treatment. They show efficacy comparable to the first-line hypnotics, with fewer cardinal side-effects. However, one should be aware of their mechanism of action and inform the patient of what to expect. The soporific effect after taking DORAs is not as clearly perceivable as in the BZDs or Z-hypnotics, especially if they had previous experience with these medications. Subjectively, the sleep onset typically comes "quietly", or more "naturally", and for this reason, patients may perceive orexin blockers to be ineffective. The objective measurements, on the other hand, do not suggest that the DORAs are inferior to other hypnotics, with lemborexant showing marginally better results in the short period since introduction. The residual somnolence 
Table 1

Comparison between common and novel hypnotics

\begin{tabular}{l|c|c|c|c} 
Drug & Duration & Onset of Action (min) & Dose (mg) & Half-life (h) \\
\hline suvorexant & intermediate & $30-60$ & $10-20$ & 12 \\
\hline lemborexant & long & $30-60 ?$ & $5-10$ & $17-19$ \\
\hline zolpidem & short & 30 & $5-10$ & 2.5 \\
\hline zaleplon & short & $15-30$ & $10-20$ & 1 \\
\hline eszopiclone & intermediate & 30 & $1-3$ & 6 \\
\hline ramelteon & short & $30-45$ & 8 & $1-2.6$ \\
\hline diazepam & long & $15-30$ & $5-10$ & 43 \\
\hline lorazepam & intermediate & $30-60$ & $1-2$ & 14 \\
\hline triazolam & short & $15-30$ & $0.125-0.25$ & 2.9 \\
\hline clonazepam & long & $30-60$ & $0.5-1$ & 23 \\
\hline
\end{tabular}

remains one of the major concerns, but the absence of tolerance and good safety profiles present an advantage. These medications should be particularly considered in elderly patients who are at a greater risk of falls and cognitive impairment, which is potentiated when using conventional hypnotics ${ }^{[27,28]}$. Another area of interest is the use of DORAs in psychiatric population, with some promising initial findings. Wider clinical use in coming years will better define their place and role in the treatment of insomnia in general, and in specific populations and medical disorders.

\section{CONFLICT OF INTEREST}

None. 


\section{TERAPIJA NESANICE \\ DVOJNIM OREKSINSKIM \\ RECEPTORSKIM \\ ANTAGONISTIMA}

\section{Nikola Trajanović}

UDK: 619.959 .7

doi: 10.5937/engrami41-29093

\section{Sažetak}

Dvojni antagonisti oreksinskih receptora su nova grupa lekova koja se nametnula kao kompetentna zamena za hipnotike izbora. Oni imaju relativno retka neželjena dejstva koja se u većini slučajeva dobro podnose, i to prvenstveno u obliku rezidualne pospanosti, umora i noćnih mora/uznemiravajućih snova. Prednost u odnosnu na konvencionalne hipnotike proizilazi iz specifičnosti njihovih ciljnih receptora, i ogleda se kroz odsustvo stvarnja tolerancije posle dugotrajne upotrebe, kao i kroz povoljan sigurnosni profil. Ovi lekovi se posebno nameću u nekim od posebnih grupa pacijenata, kao što su starije osobe. Trenutna i buduća istraživanja su orijentisana ka proučavanju njihovog uticaja na pojedinačne grupe oboljenja, kao što su bolesti zavisnosti i psihijatrijski poremećaji, demencije, stanja vezana za menopauzu i poremećaji cirkadijalnog ritma, između ostalih. 


\section{LITERATURE / LITERATURA}

1. Schutte-Rodin S, Broch L, Buysse D, Dorsey C, Sateia M. Clinical guideline for the evaluation and management of chronic insomnia in adults. $J$ Clin Sleep Med. 2008;4(5):487-504.

2. Taylor D, et al. Comorbidity of chronic insomnia with medical problems. Sleep. 2007;30:213-8

3. Sateia MJ, Buysse DJ, Krystal AD, Neubauer DN, Heald JL. Clinical Practice Guideline for the Pharmacologic Treatment of Chronic Insomnia in Adults: An American Academy of Sleep Medicine Clinical Practice Guideline. J Clin Sleep Med. 2017 Feb 15;13(2):307-349. doi: 10.5664/jcsm.6470. PMID: 27998379; PMCID: PMC5263087.

4. Matheson E, Hainer BL. Insomnia: Pharmacologic Therapy. Am Fam Physician. 2017 Jul 1;96(1):29-35. PMID: 28671376.

5. Chiu HY, Lee HC, Liu JW, Hua SJ, Chen PY, Tsai PS, Tu YK. Comparative Efficacy and Safety of Hypnotics for Insomnia in Older Adults: A Systematic Review and Network Metaanalysis. Sleep. 2020 Nov 29:zsaa260. doi: 10.1093/sleep/zsaa260.

6. Ratti E, Carpenter DJ, Zamuner S, Fernandes S, Squassante L, Danker-Hopfe $\mathrm{H}$, Archer G, Robertson J, Alexander R, Trist DG, Merlo-Pich E. Efficacy of vestipitant, a neurokinin-1 receptor antagonist, in primary insomnia. Sleep. 2013 Dec 1;36(12):1823-30. doi: 10.5665/ sleep.3208. PMID: 24293756; PMCID: PMC3825431.

7. Sakurai T, Amemiya A, Ishii M, Matsuzaki I, Chemelli RM, Tanaka H, Williams SC, Richardson JA, Kozlowski GP, Wilson S, Arch JR, Buckingham RE, Haynes AC, Carr SA, Annan RS, McNulty DE, Liu WS,
Terrett JA, Elshourbagy NA, Bergsma DJ, Yanagisawa M (February 1998). Orexins and orexin receptors: a family of hypothalamic neuropeptides and G protein-coupled receptors that regulate feeding behavior. Cell.92(4): 573-85. doi:10.1016/S0092-8674(00)80949-6. PMID: 9491897

8. de Lecea L, Kilduff TS, Peyron C, Gao $X$, Foye PE, Danielson PE, Fukuhara C, Battenberg EL, Gautvik VT, Bartlett FS 2nd, Frankel WN, van den Pol AN, Bloom FE, Gautvik KM, Sutcliffe JG. The hypocretins: hypothalamus-specific peptides with neuroexcitatory activity. Proc Natl Acad Sci U S A. 1998 Jan 6;95(1):322-7. doi: 10.1073/pnas.95.1.322. PMID: 9419374

9. Marcus JN, Elmquist JK (2006). "Chapter 3. Orexin Projections and Localization of Orexin Receptors". In Nishino S, Sakurai $T$ (eds.). The Orexin/Hypocretin System: Physiology and Pathophysiology. Springer. Pp 21-43 ISBN 9781592599509.

10. Herring WJ, Snyder E, Budd K, Hutzelmann J, Snavely D, Liu K, Lines C, Roth T, Michelson D. Orexin receptor antagonism for treatment of insomnia: a randomized clinical trial of suvorexant. Neurology. 2012 Dec 4;79(23):2265-74. doi: 10.1212/ WNL.0b013e31827688ee. Epub 2012 Nov 28. PMID: 23197752.

11. Kishi T, Matsunaga S, Iwata N. Suvorexant for Primary Insomnia: A Systematic Review and Meta-Analysis of Randomized Placebo-Controlled Trials. PLoS One. 2015 Aug 28;10(8):e0136910. doi: 10.1371/ journal.pone.0136910. PMID: 26317363; PMCID: PMC4552781.

12. Kuriyama A, Tabata H. Suvorexant for the treatment of primary insomnia: $A$ systematic review and meta-analysis. 
Sleep Med Rev. 2017 Oct;35:1-7. doi: 10.1016/j.smrv.2016.09.004. Epub 2016

Oct 28. PMID: 28365447.

13. Rosenberg R, Murphy P, Zammit G, Mayleben D, Kumar D, Dhadda S, Filippov G, LoPresti A, Moline M. Comparison of Lemborexant With Placebo and Zolpidem Tartrate Extended Release for the Treatment of Older Adults With Insomnia Disorder: A Phase 3 Randomized Clinical Trial. JAMA Netw Open. 2019 Dec 2;2(12):e1918254. doi: 10.1001/ jamanetworkopen.2019.18254. PMID: 31880796; PMCID: PMC6991236.

14. Sun H, Kennedy WP, Wilbraham D, Lewis N, Calder N, Li X, Ma J, Yee KL, Ermlich S, Mangin E, Lines C, Rosen L, Chodakewitz J, Murphy GM. Effects of suvorexant, an orexin receptor antagonist, on sleep parameters as measured by polysomnography in healthy men. Sleep. 2013 Feb 1;36(2):259-67. doi: 10.5665/ sleep.2386. PMID: 23372274; PMCID: PMC3542986.

15. Struyk A, Gargano C, Drexel M, Stoch SA, Svetnik V, Ma J, Mayleben D. Pharmacodynamic effects of suvorexant and zolpidem on EEG during sleep in healthy subjects. Eur Neuropsychopharmacol. 2016 Oct;26(10):1649-56. doi: 10.1016/j. euroneuro.2016.07.002. Epub 2016 Aug 20. PMID: 27554636.

16. Borchert JS, Wang B, Ramzanali M, Stein AB, Malaiyandi LM, Dineley KE. Adverse Events Due to Insomnia Drugs Reported in a Regulatory Database and Online Patient Reviews: Comparative Study. J Med Internet Res. 2019 Nov 8;21(11):e13371. doi: 10.2196/13371. PMID: 31702558; PMCID: PMC6874799.

17. Schoedel KA, Sun H, Sellers EM, Faulknor
J, Levy-Cooperman N, Li X, Kennedy WP, Cha JH, Lewis NM, Liu W, Bondiskey P, McCrea JB, Panebianco DL, Troyer $M D$, Wagner JA. Assessment of the Abuse Potential of the Orexin Receptor Antagonist, Suvorexant, Compared With Zolpidem in a Randomized Crossover Study. J Clin Psychopharmacol. 2016 Aug;36(4):314-23. doi: 10.1097/ JCP. 0000000000000516 . PMID: 27253658.

18. Kärppä M, Yardley J, Pinner K, Filippov G, Zammit G, Moline M, Perdomo C, Inoue $\mathrm{Y}$, Ishikawa K, Kubota N. Long-term efficacy and tolerability of lemborexant compared with placebo in adults with insomnia disorder: results from the phase 3 randomized clinical trial SUNRISE 2. Sleep. 2020 Sep 14;43(9):zsaa123. doi: 10.1093/sleep/zsaa123. PMID: 32585700; PMCID: PMC7487867.

19. Muehlan C, Vaillant C, Zenklusen I, Kraehenbuehl S, Dingemanse J. Clinical pharmacology, efficacy, and safety of orexin receptor antagonists for the treatment of insomnia disorders. Expert Opin Drug Metab Toxicol. 2020 Sep 9. doi: 10.1080/17425255.2020.1817380. Epub ahead of print. PMID: 32901578.

20. Vermeeren A, Vets E, Vuurman EF, Van Oers AC, Jongen S, Laethem T, Heirman I, Bautmans A, Palcza J, Li X, Troyer MD, Wrishko R, McCrea J, Sun H. On-the-road driving performance the morning after bedtime use of suvorexant 15 and $30 \mathrm{mg}$ in healthy elderly. Psychopharmacology (Berl). 2016 Sep;233(18):3341-51. doi: 10.1007/s00213-016-4375-x. Epub 2016 Jul 16. PMID: 27424295; PMCID: PMC4989000.

21. Trajanovic NN, Milovanovic SD. Upotreba hipnotika u rizičnim grupama pacijenata. Engrami. 2014, vol. 36, (1-2): 37-50. doi: 
10.5937/engrami1402037T.

22. Zeitzer JM, Joyce DS, McBean A, Quevedo YL, Hernandez B, Holty JE. Effect of Suvorexant vs Placebo on Total Daytime Sleep Hours in Shift Workers: A Randomized Clinical Trial. JAMA Netw Open. 2020 Jun 1;3(6):e206614. doi: 10.1001/jamanetworkopen.2020.6614. PMID: 32484552; PMCID: PMC7267849.

23. Xu S, Cui Y, Shen J, Wang P. Suvorexant for the prevention of delirium: A metaanalysis. Medicine (Baltimore). 2020 Jul 24;99(30):e21043. doi: 10.1097/ MD.0000000000021043. PMID: 32791676; PMCID: PMC7386982.

24. Herring WJ, Ceesay P, Snyder E, Bliwise D, Budd K, Hutzelmann J, Stevens J, Lines C, Michelson D. Polysomnographic assessment of suvorexant in patients with probable Alzheimer's disease dementia and insomnia: a randomized trial. Alzheimers Dement. 2020 Mar;16(3):541551. doi: 10.1002/alz.12035. Epub 2020 Jan 15. PMID: 31944580.

25. James MH, Aston-Jones G. Introduction to the Special Issue: "Making orexin-based therapies for addiction a reality: What are the steps from here?". Brain Res. 2020 Mar 15;1731:146665. doi: 10.1016/j. brainres.2020.146665. Epub 2020 Jan 10. PMID: 31930996; PMCID: PMC7181304.

26. Hopf FW. Recent perspectives on orexin/ hypocretin promotion of addiction-related behaviors. Neuropharmacology. 2020 May 15;168:108013. doi: 10.1016/j. neuropharm.2020.108013. Epub 2020 Feb 15. PMID: 32092435.

27. Edmonds C, Swanoski M. A Review of Suvorexant, Doxepin, Ramelteon, and Tasimelteon for the Treatment of Insomnia in Geriatric Patients. Consult Pharm. 2017 Mar 1;32(3):156-160. doi: 10.4140/
TCP.n.2017.156. PMID: 28270270.

28. Takeuchi Y, Sano H, Asai Y, Miyazaki M, Iwakura M, Maeda Y. Real-world evidence of the safety and efficacy profile of suvorexant in elderly patients with insomnia: a sub-analysis of the post-marketing drug-use results survey in Japan. Curr Med Res Opin. 2020 Mar;36(3):465-471. doi: 10.1080/03007995.2019.1700361. Epub 2019 Dec 20. PMID: 31793350.
Nikola Trajanović eurosomnolog@gmail.com 